\title{
A STUDY ON QUALITY IMPROVEMENT OF BITUMINOUS MIX USING CRMB AND WASTE GRANITE POWDER
}

\author{
Santosh B. C. ${ }^{1}$, Vidyashree H. H. ${ }^{2}$ \\ ${ }^{I}$ Assistant Professor, Department of Civil Engineering, S.G.Balekundri Institute of Technology, Belagavi, India \\ santoshbc90@gmail.com \\ ${ }^{2}$ Assistant Professor, Department of Civil Engineering, S.G.Balekundri Institute of Technology, Belagavi, India \\ vidyashreehavaldar@gmail.com
}

\begin{abstract}
The paper includes the experimental study of using locally available granite powder as fine aggregate and partial replacement of dust in the preparation of mould under Marshall Stability apparatus with using CRMB (Crumbed rubber modified bitumen) as a binding materials. The percentage of granite powder added by weight was 0, 25, 50, and 100\% as a replacement of dust in bituminous concrete layer. The test results show clearly that up to $100 \%$ of granite powder can be used in replacement of dust with a increase in stability.
\end{abstract}

Keywords: Crumbed rubber modified bitumen(CRMB), Granite powder, Marshal Stability apparatus.

\section{INTRODUCTION}

It was found that the addition of some material to replace bitumen to little extent will improve some desirable properties of the bituminous mixes, these material are called as MODIFIERS. When the conventional bitumen is premixed with modifiers then this bitumen is called as MODIFIED BITUMEN. For present study CRMB 55 has been used as a binder and granite powder has collected from the Ilkal quarry Bagalkot.

\section{OBJECTIVES}

The properties of bituminous mixes get improved and life of pavement gets enhanced

$>$ To obtain high flow value and high stability of the mix.

$>$ The reduction in waste generation from the granite stone quarry

Environment protection

\section{LIMITATIONS}

A detailed Marshal Stability test procedure is carried out in the laboratory with room temperature. Most of the waste granite available is in the powder form which having size less than $0.075 \mathrm{~mm}$.

\section{SCOPE}

To minimize the environmental waste produced in stone quarries. To make use of waste granite powder in the construction of flexible pavement with binder as Crumbed Rubber Modified Bitumen.

\section{PRESENT INVESTIGATION}

A General
For the present investigation, from the literature supplied, the crumb rubber was found to be prepared by combining chemically treated scrap rubber and hydrocarbon additives into a single product.

AGGREGATE: Aggregate available in and around Belagavi was selected for the preparation of specimen.

AGGREGATE GRADATION: Gradation as per MORTH 1996 is given in below table.

\begin{tabular}{|c|c|c|}
\hline SI No & Sieve Size, mm & $\begin{array}{c}\text { Percentage } \\
\text { Passing, } \%\end{array}$ \\
\hline 1 & 26.5 & 100 \\
\hline 2 & 19 & $79-100$ \\
\hline 3 & 13.2 & $59-79$ \\
\hline 4 & 9.5 & $52-72$ \\
\hline 5 & 4.75 & $35-55$ \\
\hline 6 & 2.36 & $28-44$ \\
\hline 7 & 1.18 & $20-34$ \\
\hline 8 & 0.6 & $15-27$ \\
\hline 9 & 0.3 & $10-20$ \\
\hline 10 & 0.15 & $5-13$ \\
\hline 11 & 0.075 & $2-8$ \\
\hline
\end{tabular}

B Materials used

\begin{tabular}{|c|c|c|}
\hline SI No & $\begin{array}{c}\text { Type of Aggregate } \\
\text { and Bitumen }\end{array}$ & Specific Gravity \\
\hline 1 & Coarse aggregate & 2.71 \\
\hline 2 & Fine aggregate & 2.65 \\
\hline 3 & CRMB -55 Grade & 1.02 \\
\hline
\end{tabular}


C Properties of Materials

\begin{tabular}{|c|c|c|}
\hline $\begin{array}{c}\text { SI } \\
\text { No }\end{array}$ & Property Tested & Results \\
\hline 1 & Crushing value & $23 \%$ \\
\hline 2 & Impact value & $20.86 \%$ \\
\hline 3 & Specific Gravity & 2.65 \\
\hline 4 & Penetration & 58 \\
\hline 5 & Softening point & 45 \\
\hline 6 & Ductility at 27c & $80 \mathrm{~cm}$ \\
\hline 7 & Specific Gravity of CRMB & 1.02 \\
\hline
\end{tabular}

\section{PREPARATION OF TEST SPECIMEN}

The apparatus consists of a cylindrical mould, $10.16 \mathrm{~cm}$ diameter and $6.35 \mathrm{~cm}$ height, with a base plate and collar. A compaction pedestal and hammer are used to compact a specimen by $4.54 \mathrm{~kg}$ weight with $45.7 \mathrm{~cm}$ height of fall. A sample extractor is used to extrude the compacted specimen from the mould.

1. 1200gm of aggregate is taken and heated to a temperature of $170^{\circ} \mathrm{C}$ to $180^{\circ} \mathrm{C}$.

2. Place the compaction mould, collar and rammer in oven for heating to a temperature of $100^{\circ} \mathrm{C}$ to $140^{\circ} \mathrm{C}$.

3. Required quantities of bitumen (CRMB) is taken and heats it to a temperature of $120^{\circ} \mathrm{C}$ to $140^{\circ} \mathrm{C}$ and mix it thoroughly to get homogenous mix.

4. Add the bitumen to aggregates, after it attains required temperature and mix it thoroughly till all aggregates coated completely and uniformly.

5. Continue heating of the mix till it attains a temperature of $160^{\circ} \mathrm{C}$ to $180^{\circ} \mathrm{C}$.

6. Place the mould of $10.16 \mathrm{~cm}$ diameter and $6.35 \mathrm{~cm}$ height on base plate and transfer the bituminous mix in to the mould and 75 blows are applied on either side of the specimen.

7. After 24 hours, specimen is extruded from the mould and the diameter and mean height of the specimens are measured and then they are weighed in air and also suspended in water

\section{A Testing of specimen for stability}

- The specimens are kept immersed in water in a thermostatically controlled water bath at $55^{\circ} \mathrm{C}$ for 30 to 40 minutes.

- The specimen is taken out and placed in the Marshall Test head to determine Marshall Stability value which is the maximum load in $\mathrm{kg}$ before failure and the Flow value which is the deformation of the specimen in $0.25 \mathrm{~mm}$ up to maximum load.

- The corrected Marshall stability value of each specimen is determine by applying the appropriate correction factor, if average height of the specimen is not exactly $63.5 \mathrm{~mm}$
B Correction Factors for Marshall Stability values

\begin{tabular}{|c|c|c|}
\hline $\begin{array}{c}\text { Volume of } \\
\text { specimen in cc }\end{array}$ & $\begin{array}{c}\text { Thickness of } \\
\text { specimen in mm }\end{array}$ & Correction factor \\
\hline $471-482$ & 58.7 & 1.14 \\
\hline $483-495$ & 60.3 & 1.09 \\
\hline $496-508$ & 61.9 & 1.04 \\
\hline $509-522$ & 63.5 & 1.00 \\
\hline $523-535$ & 65.1 & 0.96 \\
\hline $536-546$ & 66.7 & 0.93 \\
\hline $547-559$ & 68.3 & 0.89 \\
\hline
\end{tabular}

C Calculation of Optimum Binder content

\begin{tabular}{|c|c|}
\hline$\%$ Bitumen content & Stability $(\mathrm{Kg})$ \\
\hline 4.5 & 1660 \\
\hline 5 & 2455 \\
\hline 5.5 & 2800 \\
\hline 6 & 2658 \\
\hline 6.5 & 2020 \\
\hline
\end{tabular}

To calculate the Optimum binder content for Bituminous Concrete layer, Marshal Stability tests were carried out with varying bitumen (CRMB) content.

\section{RESULTS AND DISCUSSIONS:}

Marshall Test results of compacted mix types containing the optimum binder CRMB-55 with stone dust and waste granite powder are tabulated in table. The tables contains the value of optimum bitumen content, with varying granite powder content in terms of percent $(25 \%, 50 \%, 75 \%$ and $100 \%$ ) in replace of stone dust.

\begin{tabular}{|c|l|l|}
\hline $\begin{array}{l}\text { Optimum } \\
\text { Bitumen Content } \\
\text { (OBC) }\end{array}$ & Granite Powder & Stability (Kg) \\
\hline \multirow{3}{*}{$5.5 \%$} & $25 \%$ & 3929 \\
\cline { 2 - 3 } & $50 \%$ & 4514 \\
\cline { 2 - 3 } & $75 \%$ & 3991 \\
\cline { 2 - 3 } & $100 \%$ & 4430 \\
\hline
\end{tabular}

\section{CONCLUSIONS:}

The Marshall Stability values obtained for these four types of fillers reveal that with the optimum binder content of $5.5 \%$ and of the $50 \%$ granite powder in replace of stone dust in the Marshal Stability test, the specimen is found to exhibit higher stability value $(4514 \mathrm{Kg})$ 


\section{REFERENCES}

[1] Dr.L.R. Kadiyali; "Traffic Engineering and Transport Planning" Khanna Publishers, Seventh Edition, 2012

[2] Dr.S.K. Khanna and Dr.C.E.G. Justo; "Highway Engineering" Nem Chand \& Bros, Roorkee, U.K India, $9^{\text {th }}$ edition 2011

[3] Highway safety code. IRC :SP:44:1994

[4] AASHTO-Geometric design of highways and street

[5] Prefeasibility Report- Outer Ring Road, Belgaum, Directorate of Urban Land Transport; Deloitte Touche Tohmatsu India Private Limited April 2012

[6] www.wikipedia.org 